\title{
An Evaluation of the Kenya National Examinations Council's Application of the Deterrence Mechanism in Combating Examination Malpractices among Teachers
}

\author{
Edward Maina Andafu (PhD)* \\ School of Education, Kenyatta University, P.O. Box 43844-00100, Nairobi, Kenya
}

\begin{abstract}
In most world education systems, examination is the main tool used not only to assess and determine the learners' progress to the next level of education, but also to evaluate teachers' pedagogical competence by providing feedback to the teaching and learning process. Granted their significance in the education process, examination bodies ought to ensure that they are conducted honestly in order to serve their intended purpose. In Kenya, the Kenya National Examinations Council (KNEC) is the body that conducts national examinations in primary and secondary schools, and other tertiary institutions of education. It has hence formulated legislation to govern the conduct of the Kenya Certificate of Primary Education (KCPE) and the Kenya Certificate of Secondary School Education (KCSE) examinations. In order to enforce the said legislation, it institutes deterrent measures to safeguard the integrity of these examinations. Despite awareness of the established legislation and application of deterrent measures, some teachers indulge in examination malpractices. This scenario demonstrates the phenomenon of akrasia, the state of acting against one's will. The effectiveness of the deterrence strategy in combating examination vices is hence questionable, necessitating the need to reconsider its application. This study recommends the use of the rational approach to inculcate examination integrity among teachers in order to overcome akratic tendencies and ultimately actualize their moral potentialities.
\end{abstract}

Key Terms: Akrasia, Debate, Deterrence, Examination integrity, Kenya National Examinations Council, Rationalism

DOI: $10.7176 / \mathrm{JEP} / 11-6-17$

Publication date: February $29^{\text {th }} 2020$

\section{Introduction}

The initiative by the Kenya National Examinations Council (KNEC) to stamp out examination vices among teachers during the national examinations in primary and secondary schools seems to bear minimal success. This is attested by the recurrent incidents of the vice whenever these examinations are conducted. The establishment of legislation and institution of stringent deterrent measures to deter teachers from indulging in examination vices is however yet to ameliorate the problem (Andafu, 2019). This paper analyses KNEC's application of the deterrent strategy in combating examination vices and proposes application of the rational approach that would facilitate actualization of the teachers' moral potential. The paper comprises six sections. The first section provides an overview of examination legislation that governs the national examinations in Kenyan schools while the second one examines incidents of examination malpractices among teachers in the recent past. Section three analyses the phenomenon of akrasia with regard to how it is manifested among some teachers during the examination process. KNEC's application of the deterrence mechanism in curbing examination vices is contained in section four, while section five explores the role of debate as a teaching strategy of inculcating examination integrity among teachers. The sixth section provides an analysis of the main themes of discussion and proposes the use of debate that would facilitate activation of the teachers' rational faculty in order to actualize their moral potentiality.

\section{Established legislation to govern national examinations in Kenyan schools.}

In most world education systems, examinations are used to assess not only the learners' academic achievement but also the teachers' competence with regard to content delivery. Granted the importance of examination in an education system and the need to safeguard its credibility, world examination bodies have established legislation to govern the conduct of examinations.

In Kenya, the rules and regulations governing school examinations are contained in the KNEC Act No.29 of 2012. This is an Act of parliament that provides for the repeal of the KNEC Act CAP 225 of 1980 and the establishment of the Kenya National Examinations Council (Republic of Kenya, 2012). The Act empowers KNEC to conduct the Kenya Certificate of Primary Education (KCPE) and the Kenya Certificate of Secondary Education (KCSE) examinations. The Act outlines examination rules, offences and penalties attached to the same in case of breach. Since examination integrity is ethical in nature, it is incorporated in the Teachers Service Commission (TSC) Code of Conduct and Ethics. This Code is established by TSC and it spells standards of ethical conduct and behaviour to be observed by teachers in line with their profession. Part of the ethical conduct concerns the conduct of examination. It states that teachers should evaluate learners honestly and that they should ascertain that 
examinations are conducted without cheating (Republic of Kenya, 2014a).

The TSC Code of Regulations outlines offences which teachers may be taken to account and the mechanisms of effecting disciplinary action in the event of breach. With regard to examinations, it outlaws the possession of, or dissemination of examination material without authority (Republic of Kenya, 2014b). Teachers are deemed to have read the rules contained in the said documents and obliged to comply with them. Extracts from the said documents are also contained in the examination packages in form of instructions to examiners and candidates (KNEC, 2017; KNEC, 2018). The teachers contracted by KNEC to take part in the examination processes are taken through briefing sessions before embarking on their respective duties. Therefore they are very much acquainted with examination rules and any breach of the same is deliberate, culminating in punitive disciplinary measures. In this case, noncompliance with examination rules can be attributed to the conflict between knowledge and action.

\section{Examination malpractices}

Due to the critical role of examination in an education system, some teachers indulge in examination malpractices in order to attain higher scores for their schools. Generally, examination malpractices point to the behaviour that deviates from the laid out rules and regulations that govern the conduct of examination processes. Oluyeba and Daromola (1992) take examination malpractices to be any irregular behaviour exhibited by a person in relation to the conduct of examination. Such conduct can occur before, during or after the examination process, as long as it infringes on the laid out procedure of the examination cycle. This explanation takes into account acts such as attempts to access examination material before the due time, unauthorized possession of examination material and even fraudulently replacing the original answer script of a candidate, among others (Republic of Kenya, 2012). Examination malpractices appear to be as old as the examination itself, though efforts to stamp them out have been unsuccessful. A study conducted by the Institute of Economic Affairs in (2016) indicates that teachers are among the perpetrators of examination malpractices in the school examinations in Kenya. Some of them collude with KNEC officials to access examination papers in advance so that their candidates attain high scores. Kibwithia and Thinguri (2015) reveal that some teachers engage in the 'cleaning of scores' at a fee during the marking process. This refers to the fraudulent altering of their preferred candidates' scores by replacing the poor ones with better ones. According to the Ministry of Education, Science and Technology (MOEST), at least 50 teachers were charged in court with examination related offences during the 2015 national examinations (MOEST, 2016). Nyaundi and Imende (2019) note that the Teachers Service Commission banned 160 teachers from taking part in examination exercise after being found guilty of indulgence in examination malpractices. In addition, 11 teachers from Milimani Ramasha Academy in Kisii County were arrested over allegations of impersonation in the KCSE examinations (Abuga and Omollo, 2019). The following table contains a summary of statistics of teachers' indulgence in examination malpractices in the recent past.

Table: Statistics of the teachers' involvement in examination malpractices in the KCPE and KCSE examinations

\begin{tabular}{|l|l|}
\hline CONTRACT YEAR & REPORTED CASES \\
\hline $2012 / 2013$ & 7 \\
\hline $2013 / 2014$ & 1 \\
\hline $2014 / 2015$ & 3 \\
\hline $2015 / 2016$ & 6 \\
\hline $2016 / 2017$ & 63 \\
\hline $2017 / 2018$ & 10 \\
\hline GRAND TOTAL & $\mathbf{9 0}$ \\
\hline
\end{tabular}

\section{Source: (Teachers Service Commission, 2018)}

The statistics from the table reveal that examination malpractices is a recurrent phenomenon at every national examinations cycle. This implies that the deterrence strategies employed by KNEC to combat examination malpractices are unsuccessful. It then necessitates a change of strategy in order to ameliorate the vice. The trend of occurrence of examination malpractices shown in the table casts doubt on the effectiveness of KNEC's deterrent approach to combat examination malpractices.

\section{The phenomenon of akrasia in relation to the teachers' failure to actualize their moral potentiality}

As illustrated in section 3, some teachers contravene sections of the rules and regulations governing examinations despite being aware of what they prescribe and the attached penalties in case of breach. In Philosophy, such a tendency of acting contrary to one's knowledge is referred to as akrasia. Therefore, the teachers' indulgence in examination malpractices is a manifestation of akratic tendencies. Akrasia, also referred to as incontinence refers to a tendency of behaving contrary to one's knowledge and judgment. Audi (1991) explains that the term is Greek in origin, referring to the weakness of the human will. It is exhibited in intentional behaviour that conflicts with the agent's established values and principles. Akrasia contrasts with enkrateia or continence, which connotes 
strength of the will or self-control. Therefore akrasia is one's inability to translate their knowledge and judgment into corresponding action.

The phenomenon of akrasia dates back to the classical era. Socrates, in Plato's Protagoras (translated by Jowett, 1956), however denies the existence of akrasia by arguing that there is no way a person can judge, for instance 'x,' to be the right action then act contrary. He contends that akrasia does not exist because nobody can settle for a contrary course of action rather than the one they have judged to be right. He attributes cases of people acting contrary to their judgments to ignorance. He claims that it is a paradox for one to act against their moral judgment, unless they lack the knowledge of virtue. Rorty (1980) observes that Socrates advances two main standpoints regarding akrasia. These are: (i) a person cannot voluntarily act immorally; (ii) a person who acts virtuously possesses the knowledge of virtue. Both Plato and Socrates maintain that possession of knowledge of virtue translates to moral acts, and that immoral acts proceed from ignorance of the same. They hold that akratic actions do not exist because no one can deliberately act against their judgment. Socrates argues that acting contrary to self-judgment implies lack of real knowledge (episteme), which cannot be swayed or distracted by external interference. He maintains that when a person possesses such knowledge, they act in consonant with it, but not otherwise. Socrates' stance however contradicts what transpires in reality, as people seldom behave contrary to their knowledge. The teachers' noncompliance with examination rules despite being conversant with them demonstrates the phenomenon of akrasia, but not ignorance.

In Plato's Protagoras (compiled by Elwany, translated by Jowett, n.d.), Socrates contends that by nature, human beings act in a way that they are convinced that is good thus nobody commits evil willingly. In real life however, not all wrong acts can be attributed to ignorance because the agent must have exercised reason before acting. In relation to Socrates' stance, Brickhouse and Smith (1994) observe that in Plato's Protagoras, Socrates attributes wrong acts to deception by the power of 'appearance.' The power of appearance according to Socrates is the physical appearance of an object, which is mere illusion or a shadow of the real. The true object belongs to the intelligible world. He therefore gives prominence to the rationalism as a source of human knowledge and understanding. According to Socrates, akrasia does not exist because human behaviour is guided by knowledge. In this argument it is in Socrates' contention that knowledge exists absolutely in the form of ideas that has to be attained through intellectual discourse. The shadow he alludes to is the superficial knowledge or mere awareness that does not stem from the intellect.

What Socrates says in the Plato's Protagoras and Meno appears to contradict what he alludes to in the Republic, regarding knowledge and acting (Dorter, 2008). In the former dialogues he defends the position that knowledge possession informs right actions. However, in the Republic (translated by MacDonald, 1945) Socrates contradicts his position by acknowledging that it is possible for one to have knowledge but act otherwise. He employs the model of the tripartite soul to account for akratic tendencies in human beings. He attributes immoral acts to lack of moral strength, when the irrational faculty of the soul overrides the rational one. In explaining his conception of the tripartite nature of the human soul, Plato claims that the soul constitutes three faculties, namely the rational, irrational and the spiritual. In order to maintain harmony within the soul, the rational faculty should be in charge, with the spiritual as its auxiliary; to check the irrational faculty. It is such harmony that translates to overt moral behaviour exhibited in a person. In the event that the irrational faculty overrides the rational, the harmony is destabilized, being manifested in immoral behaviour. The destabilization can be caused by strong feelings of passion or appetites which distracts one's focus and derails their thoughts. In relation to examinations for instance, the teachers' anticipated benefits that accrue from good performance in examinations such as promotion, reception of tokens from the school management and recognition can be equated to the passions and appetites that influence them to indulge in examination vices.

Plato visualizes the human person as being dual in nature; having both mind and body. The soul is the essence of the human being that determines their conduct. The soul operates on the three faculties as identified. The rational faculty is the reasoning and decision making part of the soul with the spiritual is its auxiliary, while the irrational operates on the basis of bodily emotions such as desires and appetites. Both the rational and irrational faculties are in constant struggle to control the soul. Morality within an individual is hence maintained when harmony exists in the soul. In the event that the irrational faculty overrides the rational faculty, disharmony occurs in the soul, translating to immoral conduct in a person. Going by Plato's conception of the nature of morality, it can be construed that akrasia is real and that it results from the disharmony in the functioning of the human body and mind because human conduct is a manifest of the soul. Akrasia is caused by the influence of bodily pleasures and appetites which culminate in lack of moral strength in an individual. Cognitive and emotional attributes also influence akratic behaviour, thus akrasia is both philosophical and psychological in nature. It is philosophical in the sense that it emanates from psychical disharmony within an individual and it is psychological because it is manifested in overt behaviour that is contrary to one's knowledge and will. Akratic behaviour cannot be attributed to lack of knowledge but one's inability to actualize their knowledge of morality. Strategies to overcome akrasia should hence focus on cementing the mind-body relationship so that the human thought processes translate to corresponding behaviour. However, KNEC solely relies on deterrence approach in an attempt to fight examination 
malpractices.

\section{The deterrence mechanism of punishment and its application in combating examination malpractices}

The examination rules and corresponding penalties established by the KNEC Act No. 29 of 2012 are expected to govern the conduct of examinations and at the same time act as deterrents. The cited incidents of examination malpractices however depict ineffectiveness of deterrent mechanism in curbing examination vices. Peters (1966) explains that punishment denotes infliction of unpleasant or aversive experience such as pain by someone in authority who has the right to do so. As posited by Bedau and Kelly (2015), punishment constitutes four main elements: (i) it is an intentional act; (ii) it imposes some sort of hardship, pain or loss of privilege enjoyed by the victim; (iii) the hardship, pain or loss of privilege imposed should be in response to what is perceived to be a wrongful act; (iv) the essence of punishment should be to send a message of censure or condemnation for what is perceived to be a wrong act.

Prescription of the deterrence approach in character modification is traced back in the classical era. In the dialogue Gorgias (compiled by Elwany, translated by Jowet, n.d.), Socrates advocates for the rule of law in the maintenance of order in society. Failure to comply with the established law necessitates the application of punishment as a corrective measure. He argues that punishment restores order in society and failure to apply it perpetuates vices. Socrates argues that punishment serves as a corrective measure as well as a deterrent to those who would intent to break the law. The same sentiments are echoed by Protagoras, a character in Plato's Protagoras (translated by Jowett, 1956), who reiterates the importance of punishment in shaping a child's character. He believes that punishment is a vital tool in shaping one's character.

Proponents of punishment such as Paternoster (2010) argues that punishment is justified because it serves various social control functions such as retribution, rehabilitation and deterrence. He maintains that punishment has a deterrent effect when its fear or actual imposition leads to conformity. The severe sanctions that accompany the established rules impede the likelihood of occurrence of deviant behaviour. However, punishment does not guarantee compliance with the law. The victim might devise alternative mode of misbehaviour or develop resistance to punishment. The recurrent incidents of teachers' indulgence in examination malpractices despite institution of punishment to those found guilty attests to this. From the deterrent point of view, punishment has a potential deterrent effect to compel one comply with the rules or desist from unwanted behaviour in response to the looming threat or fear of legal sanctions (Philosophies of punishment, n.d.). The teachers' persistent indulgence in examination malpractices however demonstrate the ineffectiveness of punishment as a behaviour modification strategy.

Paternoster (2010) considers Cesare Beccaria and Emmanuel Bentham as the proponents of the deterrence theory. Paternoster explains that in his work titled: On crimes and punishment (1764), he (Beccaria) contends that crimes are preventable by threats from a rational and efficient legal system and that clearly defined laws, coupled with punishment would guarantee compliance. Given this conception of deterrence, then the approach used by $\mathrm{KNEC}$ in administering national examinations is deterrent in nature. The move by the Education Cabinet Secretary to ban school cultural activities such as prayer meetings preceding examinations as noted by Too (2016) is a form of deterrence. It is aimed at deterring candidates any contact with their kin, whom in KNEC's view might expose candidates to leaked examination. In addition, during the examination the Education Cabinet Secretary leads a team of senior government officers in supervising the examinations (Wanzala, 2016). This exercise is meant to scare and intimidate teachers who might attempt to engage in examination mischief. If senior government officers take up the role of examination supervision, then what is the essence of hiring field officers (teachers) to supervise and invigilate examinations? Does it mean that KNEC no longer has confidence in the teachers they contract to administer examinations? Nevertheless, the examination marking centres are mounted with 24-hour closed circuit television (CCTV) surveillance cameras to record every activity that transpires during the marking process. In addition, teachers who mark the examinations undergo thorough security checks including frisking before they make their way into the examination marking centres (Ogutu, 2016). Such security measures are all meant to deter teachers from any attempt to engage in examination mischief during the marking process.

Although the presence of senior government officers in the examination centres is meant to deter teachers from engaging in examination vices, it might as well arouse fear and anxiety among both the teachers and candidates. Fear, tension and anxiety in turn adversely affect the smooth running of examinations as well as the candidates' eventual performance. It is scientifically proven that a tensed examination environment negatively impacts on the candidates' academic achievement (Quora, n.d.). Tension, fear and anxiety experienced by candidates when they sit examination in a threatening atmosphere is a matter that may require further investigation.

Supporting the use of deterrence, Elliot (n.d.) explains that it facilitates the achievement of control over one's conduct through fear. Such control instils fear in the potential offender who eventually does not risk indulging in the unwanted behaviour for fear of the impending consequences. Elliot further claims that deterrence as a preventative measure elicits three sorts of effects namely: intimidation, strengthening of moral inhibitions and reinforcement. While advocating for the use of deterrence in behaviour modification, Beyleveld (1979) argues that 
it inhibits occurrence of unwanted act due to the sanctions. The agent therefore refrains from the act due to the fear of impending execution of the sanctions.

However, KNEC's employment of deterrence in managing examination has achieved minimal results, thus justifying Eggen's (1994) assertion that punishment temporarily weakens the unwanted behaviour but it does not teach any new desired behaviour. The drastic reduction in the cases of examination malpractices among teachers in the 2017/2018 contractual year apparently demonstrates what deterrence can achieve in suppressing unwanted behaviour at the expense of inculcating examination integrity. Generally, the use of deterrence approach to conduct examination does not inculcate examination integrity among teachers because integrity cannot be inculcated by coercion and strict enforcement of rules. Failure to uphold examination integrity by a section of teachers does not imply that they are not conversant with the examination rules, neither are they not aware of the consequences of examination malpractices. However, it is due to their inability to translate their moral potential into action, hence acting contrary to the dictates of their profession. Inculcation of examination integrity among teachers requires the use of a teaching method that would activate their rational faculty in order think critically and make informed decisions.

\section{Debate as a teaching and learning strategy}

Since morality is a distinctive human attribute, then it follows that all teachers possess the potential to uphold examination integrity. However, the problem lies with the actualization of this potential. Actualization of the moral potential necessitates the use of a teaching strategy such as debate, which involves rigorous intellectual discourse that facilitates translation of their moral potential into corresponding actions. Ramlan, Kassim, Pakirisamy and Selvakumar (2016) define debate as a planned classroom activity in which a particular claim or idea is discussed then learners present their opinions on the motion. The essence of debate is not for either party to win the argument but to develop the learner's ability to think independently through a set of claims or arguments so as to strengthen their understanding of the theme of the debate. Debate engages participants in high level intellectual activities such as discussion, synthesis, evaluation and assessment, judgement and enable them reach informed decisions. It enhances the participants' mental capacities to reason and explore alternatives amid conflicting courses of action. Saroya (2005) argues that debate is a discourse between two or more people about a theme, exchanging ideas so as to formulate an opinion. It is meant to explore truths through interaction, thus it significantly impacts on the human mental faculty.

As a teaching strategy, debate is traced in the ancient Greece where the Sophists formulated the dialectic and rhetoric method. Socrates in his dialectic method employs debate to detect fallacies and establish the truth through logical reasoning. In Plato's Meno (translated by Jowett, 2009), Socrates demonstrates what debate can yield. He engages a slave boy (who has not studied Geometry before) in a debate until he arrives at the correct answer to a geometrical equation. Socrates concludes that the boy has not learnt anything new but instead recollected the knowledge that is implanted in his mind. This argument is based on Plato's theory of knowledge which contends that human beings possess innate knowledge stored in their minds in the form of ideas. Such ideas can be retrieved and brought to the fore as absolute knowledge (episteme). In Plato's contention, once a person possesses such knowledge, they act in consonant with it but not otherwise. Attainment of the said knowledge then requires a rigorous intellectual discourse that would facilitate critical thinking and eventual making of informed decision making. Debate as a teaching strategy would suffice as an appropriate teaching approach to foster understanding and attainment of critical consciousness. As opposed to deterrence, debate can be utilized as a teaching strategy to inculcate examination integrity among teachers.

Debate makes the teaching process to go beyond rote learning and makes the participants develop critical and analytical thinking. It enables the participants to understand the concept well as they actively and intensively engage in the learning process (Zare and Othman, 2013). Being a form of interactive learning, it not only enhances the learners' memory but also critical thinking skills, self- acceptance and self-esteem. When applied in the teaching of examination integrity, it would enable teachers to reflect on their professional expectations with regard to the conduct of examination, the role of examination in an education cycle and the need to uphold their professionalism as role models. Ramlan et al. (2016) reiterate that debate improves the learners' critical thinking skills, enhances knowledge acquisition and understanding. It offers opportunity for the learners to utilize their critical thinking skills and internalize the theme of debate. Najafi, Motaghi, Nasrabadi and Heshi (2016) support the same view by asserting that as a group-based and learner-centred approach, debate promotes mastery of learning, development of one's intellect and the power of evaluation. If well applied in the teaching process, debate would foster clear understanding of the concept as it actively involves the learner in the learning process.

\section{Analysis}

The research findings reveal that teachers still indulge in examination malpractices despite KNEC's efforts to stamp out the vice. Overreliance on deterrence as a strategy of curbing examination malpractices has apparently failed to bear fruits. This is attributed to the persistent manifestation of akratic tendencies among a section of 
teachers during the national examinations. Deterrence as noted, does not inculcate any new desired behaviour but instead temporarily suppresses the unwanted behaviour and eventually gives room for it to recur. The agent may as well develop resistance and devise new ways of perpetuating the unwanted behaviour. This explains the teachers' evolution of modern methods of cheating such as 'cleaning' grades from the rudimentary forms such as copying which have become difficult to execute.

Examination integrity necessitates development of an individual's moral orientation. Since morality stems from the human's inner-self, then examination integrity cannot be inculcated by deterrence and coercion. It requires intensive moral education that would facilitate actualization of an individual's moral potentiality. Based on Plato's conception of the dual nature of the human person, inculcation of examination integrity should be rational oriented. Human behaviour is a manifestation of the thought process hence inculcation of examination integrity among teachers should be confined to their rational attribute so as to perfect the coordination of their minds and body. As Noll (2001) argues, akrasia is influenced by possession of temporary knowledge that lacks the emotional component of the human character such as conscience and self-control. Therefore intensive rational discourse should take into account the psychical integration of the human mind and body. Such integration would facilitate the exercise of restrain and self-control in the face of moral dilemma, whereby the agent would exercise the use of reason in order to reach informed decision. That is why Aristotle (2000) contends that akrasia is caused by a deficiency in the epistemic relationship to the particular premise. The particular premise is the conclusion one arrives at after the process of mental deliberation. It is the particular premise that enables one to translate knowledge claims into corresponding action.

Granted the fact that human beings possess the moral potential, then teachers possesses the potentiality to uphold examination integrity, thus through exposure to a rigorous rational discourse they would grasp a clear understanding of their professional expectations and the need to uphold examination integrity. The discourse should take the form of a debate as an education model in preparation for examinations. The education program should be organized by KNEC, whose facilitators should engage teachers in a formal examination integrity course freely without coercion, intimidation or fear. In such a conducive atmosphere teachers are free to air their views concerning their conduct. They would have an opportunity to question the authority about the expected examination conduct, if need be and seek clarification. Such forum would facilitate exchange of ideas and experiences concerning examination and the teaching profession at large. Through such exchange teachers would understand the essence of safeguarding their integrity and they would ultimately make informed decisions concerning the need to uphold examination integrity. This program should be organized annually in preparation for the national examinations, targeting the teachers who take part in the examination exercise. The proposed education programme should focus on key themes of teacher professionalism such as honesty, tolerance, truthfulness, responsibility and accountability. With such approach, teachers would voluntarily take up their professional responsibility without compulsion and eventually uphold examination integrity.

\section{Conclusion}

The foregone discussion has established that deterrence does not instil examination integrity among teachers, leading to their manifestation of akratic tendencies. This is due to their inability to actualize their moral potential. Such actualization requires rigorous intellectual discourse, facilitated by debate in order to arouse their critical consciousness such that their moral decisions and actions emanate from their psyche. Implementation of the proposed rational model of moral education should not however replace the established examination rules, but facilitate the implementation of the same without compulsion or deterrence. It is noteworthy that not only teachers indulge in examination malpractices, but also other interested parties such as some students, parents and the security personnel deployed to guard the examination materials. There is need for a philosophical study to establish appropriate strategies to employ in order to avert examination malpractices among them.

\section{References}

Abuga, E. \& Omollo, K. (2019). '14 arrested in raid on KCSE exam cheats.' The Standard, 6 November. Available at: https://www.standardmedia.co.ke/article/2001348242/14-arrested-in-raid-on-kcse-exam -cheats (Accessed: 6 November 2019)

Andafu, E. M. (2019). A critique of Plato's conception of morality with reference to the teachers' expected examination integrity in Kenya. Doctor of Philosophy thesis of the University of Nairobi.

Aristotle. (2000). Nicomachean Ethics (Crisp Roger Trans.). Cambridge: Cambridge University Press. (Original work published in 1791).

Audi, R. (1991). The Cambridge Dictionary of Philosophy ( $2^{\text {nd }}$ ed.). New York: Cambridge University Press.

Bedau, H. A., \& Kelly, E. (2015). "Punishment," in The Stanford Encyclopedia of Philosophy (Fall 2015 Ed), Edward N. Zalta (ed.), [Online] Available at: URL $=<$ https://plato.stanford. ed/archives/fall2015/ entries/punishment/> (Accessed: 6/7/2018)

Beyleveld, D. (1979). Identifying, explaining and predicting deterrence. The British Journal of Criminology. Vol. 


\section{3, Issue 19 pp. 205-224.}

Brickhouse, T., and Smith, N. (1994). Plato's Socrates. Oxford: Oxford University Press.

Dorter, K. (2008). Weakness and will in Plato's Republic. In Tobias Hoffmann (Ed.), Weakness of will from Plato to present. Washington: Catholic University of America Press.

Eggen, P. (1994). Educational Psychology. Florida: Macmillan Publishing Company.

Elliot, B. (n.d.). Deterrence theory revisited. Unpublished Research Paper. The Land Transport Authority, New Zealand.

Institute of Economic Affairs. (2016). Cyclic nature of exam irregularities. [Online] Available at: http://www.ieakenya.or.ke/number-of-the-week-2-181-cyclic-nature-of-exam- irregularities-in-kcse (Accessed: 6/9/2016)

Kibwithia, S., \& Thinguri, R. W. (2015). A critical analysis of the effectiveness of examination policy on examination administration in Kenya. Academic Research International. Vol.6 (4), pp. 260-261.

KNEC. (2017).The 2017 KCPE examination timetable and instructions. KNEC/TD/SE/KCPE/ TT/17/006.

KNEC. (2018). The $2018 \mathrm{KCSE}$ examination timetable and instructions. KNEC/TD/SE/KCSE/TT/18/005

Najafi, M., Motaghi, Z., Nasrabadi, H. B. \& Heshi, K. N. (2016). "Debate" learning method and its implications for the formal education system. Academic Journals Vol. 11 (6), pp. 211-218.

Noll, J. W. (2001). Clashing views on controversial educational issues. Guilford: Dushkin/ McGraw-Hill Co.

Nyaundi, L. \& Imende, B. (2019). 'TSC bans teachers involved in cheating from managing exams.' The Star, 15 October. Available at: https://www.the-star.co.ke/new/2019-10-15-tsc-bans-teachers -involved-in-cheatingfrom-managing- exams/ (Accessed: 6 January 2020)

Ogutu, K. (2016). 'An insider's account of strict marking of KCSE.' The Standard, 27 November. Available at: https://www.standardmedia.co.ke/article/2000228085/an-insider-s-account-ofstrict-marking-of-kcse (Accessed: 5 December 2017)

Oluyeba, N. F., \& Daromola, S.O. (1992). Incidences and detection of examination malpractices in Nigerian public examinations. A paper presented on behalf of the West Africa Examinations Council on examination malpractices, University of Benin.

Paternoster, R. (2010). How much do we really know about criminal deterrence? Journal of Criminal Law and Criminology. Vol. 100, Issue3, pp. 764-773.

Peters, R. S. (1966). Ethics and education. London: Routledge and Keegan Paul.

Philosophies of punishment. (n.d.). [Online] Available at: https://marislute.fileswordpress.com /2010/11/sodafilozofijas-3.pdf pp. 15-24. (Accessed: 19/1/2019)

Plato. (1945). The Republic of Plato (Francis MacDonald, Trans.). London: Oxford University Press. (Original work published in $381 \mathrm{BC})$.

Plato. (1956). Plato's Protagoras (Benjamin Jowett, Trans.). New York: The Bobbs-Merill Company Inc.

Plato. (n.d.). The complete works (compiled by Mohammed Elwany, Benjamin Jowett, Trans.). [Online] Available at: http:www.cakravartin.com/wordpress/wp-content/uploads/2008/08/ plato-complete-works.pdf (Accessed: 7/7/2016)

Plato. (2009). Meno (Benjamin Jowett, Trans.). Rockville: Maryland Serenity Publishers.

Quora. (n.d.). Available at: https://www.quora.com (Accessed: 10/12/2018)

Ramlan, F. A., Kassim, N. M., Pakirisamy, S. \& Selvakuma, V. (2016). The impact of debates as a teaching strategy in the classroom to medical students. e-Academia Journal Vol. 5 Issue 2 pp. 194-203.

Republic of Kenya. (2012). Kenya National Examinations Council Act No.29 of 2012. Nairobi: National Council of law Reporting.

Republic of Kenya. (2014a). Teachers Service Commission Code of Conduct and Ethics. Nairobi: Government Printer.

Republic of Kenya. (2014b). Teachers Service Commission Code of Regulations for teachers. Nairobi: Government Printer.

Rorty, A. (1980). Essays in Aristotles' ethics. Los Angeles: University of California Press.

Soraya, S. M. (2005). Debates procedure. Tehran: Growth Publications.

Too, T. (2016). 'Radical measures to curb cheating in exams.' The Standard, 28 July. Available at: https://www.standardmedia.co.ke/article/200021004/radical-measures-to-curb(Accessed: 24 November 2016)

TSC. (2018). Statistics of teachers' involvement in the KCPE and KCSE examination malpractices from 2013/2013 to 2017/2018. TSC: Nairobi.

Wanzala, O. (2016). 'Matiang'i rules that curbed theft of tests.' Daily Nation, 1 December. Available at: https://www.nation.co.ke/education/Matiang-i-rules-that-curbed-theft-of-tests/264-3470738 -xh0tyx/indexhtml (Accessed: 12 June 2017)

Zare, P. \& Othman, M. (2013). Classroom debate as a systematic teaching/learning approach. World Applied Sciences Journal 28 (11) pp. 1506-1513. 